\title{
28. PETROLEUM-GENERATING POTENTIAL OF CRETACEOUS SEDIMENTS FROM LEG 43, DEEP SEA DRILLING PROJECT
}

\author{
J. W. Kendrick, A. Hood, And J. R. Castaño, Shell Development Company, Bellaire Research Center, P.O. \\ Box 481, Houston, Texas
}

\begin{abstract}
The petroleum-generating potential of Cretaceous sediments from the Bermuda Rise was investigated in terms of their organic richness and thermal history. The results of the study indicate that some sediments contain sufficient amounts of thermally reactive organic matter to be considered potential, or future, petroleum source rocks. None of the samples, however, have been buried deeply enough to reach the level of organic metamorphism at which significant petroleum generation begins. Visual kerogen observations indicate that reworked, terrigenous organic matter is a major component of the kerogen in many sediment samples.
\end{abstract}

\section{INTRODUCTION}

At Sites 386 and 387 on the Bermuda Rise (Figure 1), Leg 43 of the deep Sea Drilling Project (DSDP) penetrated a sequence of Cretaceous sediments, containing numerous beds of black claystones. Because similar sediments recovered at other DSDP sites in the North Atlantic (Hollister, Ewing, et al., 1972; Hayes, Pimm, et al., 1972) are frequently rich in organic matter, we obtained several sediment samples from these two sites for the purpose of evaluating their petroleumgenerating potential. Our objectives were to determine whether these sediments contain enough thermally reactive organic matter for the generation of significant quantities of petroleum, and whether they have been exposed to subsurface temperatures high enough for the thermal conversion of kerogen to petroleum. In addition, we used organic carbon data and visual kerogen analyses to characterize the types of organic matter in the sediments.

To measure the abundance of organic matter, we determined both the organic carbon $\left(\mathrm{C}_{\text {org }}\right)$ and effective carbon $\left(\mathrm{C}_{\text {eff }}\right)$ contents of the sediment samples. Organic carbon, or acid-insoluble carbon, reflects the total amount of organic matter in the sediment. It is determined by measuring the carbon dioxide evolved during combustion of an acid-treated sample. Effective carbon, on the other hand, reflects the fraction of organic carbon which is thermally convertible to petroleum. As estimates of effective carbon, we used two laboratory pyrolysis procedures. One method, pyrolysis fluorescence $(\mathrm{PF})$, is a rapid means of evaluating a sediment's petroleum-generating potential, by measuring (in arbitrary PF units) the amount of fluorescing bitumen generated on heating. PF values in rocks may range from zero to several thousand units. The second method, pyrolysis FID (P-FID), provides a measure of the hydrocarbons and hydrocarbon-like compounds produced by heating the sample from $25^{\circ}$ to $750^{\circ} \mathrm{C}$. The effective carbon content is computed as 85 per cent of the hydrocarbon generated in the temperature range of $300^{\circ}$ to $650^{\circ} \mathrm{C}$; it does not include pre-existing hydrocarbons which are distilled from the sample at lower temperatures.

The conversion of kerogen to petroleum is a temperature-dependent reaction, and the effects of organic metamorphism can be observed as changes in the chemical and physical properties of the kerogen. The reflectance (in oil) of vitrinite, a coal maceral which is disseminated in many sediments, is a commonly used method for measuring the level of organic metamorphism (LOM; Hood et al., 1975). As shown in Figure 2 , vitrinite reflectance is applicable over the wide range of coal rank and LOM in which oil and gas are formed.

The analytical techniques have been described in greater detail by Hood et al. (1976).

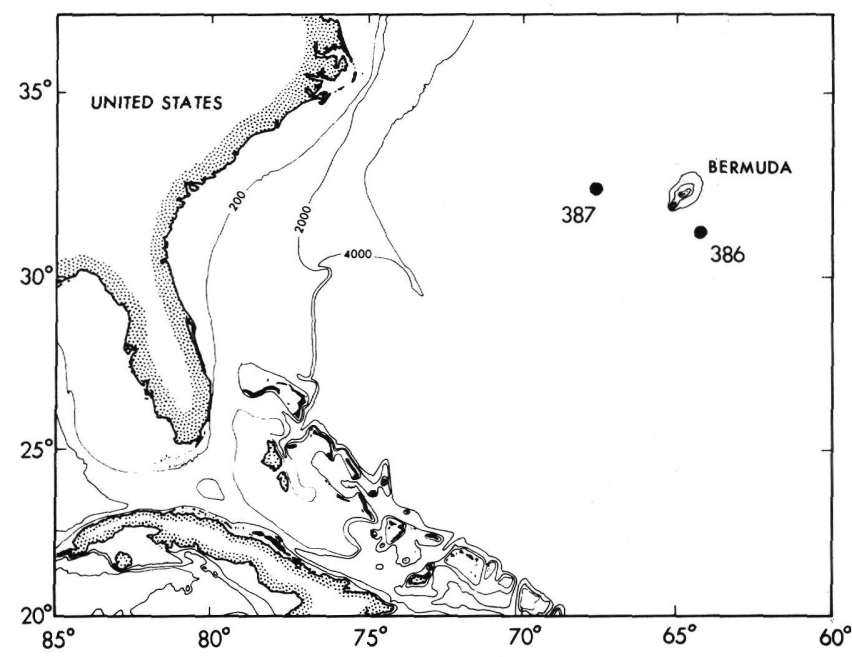

Figure 1. Location map. Depth contours in meters. 


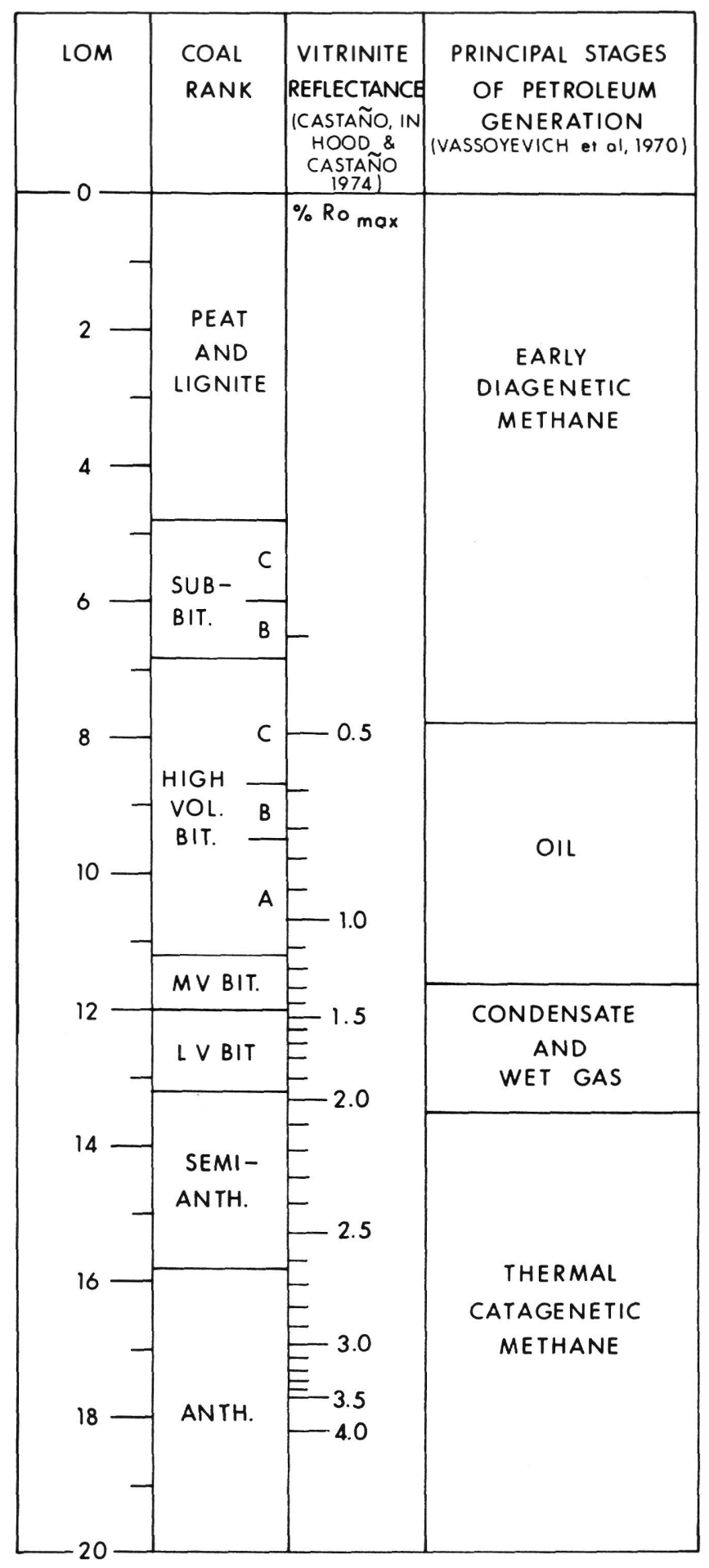

Figure 2. Scale relating coal rank, vitrinite reflectance, and petroleum generation to the level of organic metamorphism (LOM), after Hood and Castaño (1974) and Hood et al. (1975).

\section{RESULTS AND DISCUSSION}

\section{Abundance of Organic Matter}

On the basis of studies of organic carbon in petroliferous and non-petroliferous sedimentary basins (Ro- nov, 1958; Schrayer and Zarella, 1963), we generally consider 1.0 to 1.5 per cent organic carbon to be a minimum requirement for a potential source rock of petroleum. We regard pyrolysis techniques as better indicators of petroleum-generating potential, however, since they measure directly the petroleum-like material generated during heating. In this regard, we believe that sediments should have PF values greater than 10 or pyrolysis hydrocarbon yields greater than 0.30 per cent $\left(0.26 \% \mathrm{C}_{\text {eff }}\right)$ before they can be considered potential source rocks.

The organic carbon values of the Leg 43 sediments are summarized in Table 1 . The organic carbon contents of the sediments range from 0.13 to 8.9 per cent, and the effective carbon contents range from almost 0 to 4.4 per cent. The above criteria indicate that several samples from Site 386 contain enough reactive organic matter to be considered potential source rocks of petroleum. While several other samples have organic carbon contents between 1.0 and 1.5 per cent, their effective carbon contents are all less than 0.1 per cent, indicating that little petroleum could ever be generated from such sediments.

There is considerable variability in the petroleumgenerating potential of the sediments at Sites 386 and 387. This is best illustrated by comparing two subsamples from Sample 386-44-3, 139-145 cm. Subsample " $\mathrm{b}$ "- a laminated, gray-black claystone-contains 1.3 per cent $C_{\text {eff. }}$ By contrast, the adjacent subsample "a"a mottled, greenish gray claystone-contains negligible reactive organic matter. In this context, organic carbon determinations of only a few samples may not be a reliable indicator of a sedimentary unit's overall petroleum-generating potential. None of the tabulated samples from Site 387, for instance, contain enough organic carbon to be considered potential source rocks. Yet, additional measurements of effective carbon and pyrolysis fluorescence by Kendrick (this volume) indicate that source rock quality sediments do occur at Site 387.

\section{Level of Organic Metamorphism (LOM)}

Several of the samples from Leg 43 exhibit a broad distribution of vitrinite reflectance values. Because reflectance values for vitrinite in a humic coal commonly fall into a narrow range, the occurrence of broader reflectance distributions in several Leg 43 samples implies that some vitrinite either has been partially oxidized or has been recycled from sedimentary units with a prior thermal history. The influence of reworked or oxidized vitrinite can be observed in the histograms of Figure 3. Most values of vitrinite reflectance (Ro) for sample 387-44-3, 139-145b, lie in a narrow cluster around 0.3 per cent Ro and probably represent measurements of primary vitrinite. The values of Ro for Sample 386-44-3, 139-145a, on the other hand, are spread over a wide range from 0.5 to 1.2 per cent Ro. The broad distribution and high values of Ro for the second sample imply that it contains mostly reworked vitrinite. While there is very little overlap of Ro values 
TABLE 1

Measurements of Organic Carbon

\begin{tabular}{|c|c|c|c|c|c|c|c|}
\hline $\begin{array}{c}\text { Sample } \\
\text { (Interval in } \mathrm{cm} \text { ) }\end{array}$ & Depth & Age & $\% \mathrm{C}_{\text {org }}$ & $\mathrm{PF}$ & $\begin{array}{l}\% \mathrm{HC} \\
\text { from P-FID } \\
\left(300-650^{\circ}\right)\end{array}$ & $\% \mathrm{C}_{\mathrm{eff}}$ & Comments \\
\hline \multicolumn{8}{|l|}{ Site 386} \\
\hline $\begin{array}{l}43-3,135-138 \\
44-3,139-145 \mathrm{a} \\
44-3,139-145 \mathrm{~b} \\
54-5,134-140 \\
56-3,148-150 \\
57-3,137-142 \\
58-5,147-150 \\
60-5,138-141 \\
63-1,137-142\end{array}$ & $\begin{array}{l}741 \\
750 \\
750 \\
858 \\
874 \\
883 \\
896 \\
915 \\
937\end{array}$ & $\begin{array}{l}\text { Cenomanian } \\
\text { Cenomanian } \\
\text { Cenomanian } \\
\text { Albian } \\
\text { Albian } \\
\text { Albian } \\
\text { Albian } \\
\text { Lower Albian } \\
\text { Lower Albian }\end{array}$ & $\begin{array}{l}8.89 \\
0.27 \\
5.00 \\
1.10 \\
0.66 \\
0.58 \\
1.28 \\
2.40 \\
4.56\end{array}$ & $\begin{array}{r}150 \\
0 \\
240 \\
1 \\
0 \\
1 \\
5 \\
8 \\
68\end{array}$ & $\begin{array}{r}5.20 \\
<0.01 \\
1.56 \\
0.03 \\
<0.01 \\
<0.01 \\
0.05 \\
0.40 \\
0.99\end{array}$ & $\begin{array}{r}4.42 \\
<0.01 \\
1.33 \\
0.03 \\
<0.01 \\
<0.01 \\
0.04 \\
0.34 \\
0.84\end{array}$ & $\begin{array}{l}\text { Dark gray claystone } \\
\text { Mottled, greenish gray claystone } \\
\text { Dark gray-black, laminated claystone } \\
\text { Dark gray-black-fissile shale } \\
\text { Dark gray fissile shale } \\
\text { Medium gray claystone } \\
\text { Olive gray-black, laminated claystone } \\
\text { Dark olive-gray calcareous claystone } \\
\text { Olive black claystone }\end{array}$ \\
\hline \multicolumn{8}{|l|}{ Site 387} \\
\hline $\begin{array}{l}35-3,140-145 \\
36-2,140-145 \\
37-1,146-150 \\
49-4,4-8\end{array}$ & $\begin{array}{l}550 \\
558 \\
576 \\
787\end{array}$ & $\begin{array}{l}\text { Albian } \\
\text { Albian } \\
\text { Aptian } \\
\text { Valanginian }\end{array}$ & $\begin{array}{l}1.36 \\
1.29 \\
0.13 \\
0.73\end{array}$ & $\begin{array}{l}2 \\
2 \\
3 \\
6\end{array}$ & $\begin{array}{r}0.07 \\
0.08 \\
<0.01 \\
0.16\end{array}$ & $\begin{array}{r}0.06 \\
0.07 \\
<0.01 \\
0.14\end{array}$ & $\begin{array}{l}\text { Dark olive gray claystone } \\
\text { Gray-black claystone; drilling breccia? } \\
\text { Greenish gray claystone } \\
\text { Olive gray marly limestone }\end{array}$ \\
\hline
\end{tabular}

between the histograms in Figure 3, the distinction between primary and reworked vitrinite is seldom so clear. It is clear, however, that samples containing reworked vitrinite will give estimates of LOM which are too high if based on the entire population of reflectance values.

The results of the vitrinite reflectance measurements are summarized in Table 2. For each sample, an $X$ value is listed, which indicates the range and mean of all vitrinite reflectance measurements made on the sample. For some samples, an A value is also given, which indicates those measurements interpreted as primary vitrinite. A values and LOM's have been listed only for those samples in which the primary vitrinite can be distinguished readily from the histogram of vitrinite reflectance values. When the histograms of vitrinite reflectance are plotted as a function of depth (Figure 4 ), it can be seen that some histograms lie wholly to the right of the line tracing Ro for primary vitrinite. Such samples, which contain reworked virtinite almost exclusively, cannot be considered reliable indicators of LOM.

Figure 4 indicates that vitrinite reflectance at Site 386 increases from about 0.25 to 0.35 per cent. Near the base of Site 387 , Ro is about 0.25 per cent. These values of vitrinite reflectance correspond to coal ranks of lignite to sub-bituminous C and to LOM's less than seven. These low levels of organic metamorphism indicate that the sediments have not been buried deeply enough to reach the LOM of about 8 at which oil generation begins (Hood et al., 1975). Consequently, despite the high contents of organic matter in some sediments, the Cretaceous sediments can be considered only as potential, or future, source rocks of petroleum.

\section{Types of Organic Matter}

During the measurements of vitrinite reflectance, semiquantitative visual estimates of the types of organic matter were made, according to the classification scheme in Table 3. Liptinite and amorphous kerogen represent lipid-rich material which is either structured (spores, algae, etc.) or unstructured, respectively. Vitrinite represents hydrogen-lean organic matter, typically derived from land plants. Inertinite includes thermally inert macerals such as fusinite, semifusinite, and micrinite. We no longer include reworked vitrinite in the category of inertinite because of the difficulty in distinguishing primary and reworked vitrinite in many samples.

The results of the visual kerogen analyses (Table 3) are surprising because they indicate that vitrinite constitutes a major fraction of the organic matter in many of these sediments. The numerous high values of vitrinite reflectance in many samples further imply that much of the vitrinite is reworked from older sedimentary units. These observations indicate that the input of reworked, terrigenous organic matter strongly influenced the composition of organic matter in the sediments. Large amounts of amorphous kerogen, which could reflect the contribution of marine organic matter, are present in only a few samples.

Differences in the composition of organic matter observed visually are reflected in the amounts of organic carbon which are thermally convertible to petroleum. Organic matter which consists predominantly of vitrinite and inertinite tends to yield very little hydrocarbon-like material during pyrolysis. Effective carbon commonly constitutes less than 10 per cent of the organic carbon. In those samples that contain appreciable amounts of amorphous kerogen, the proportion of thermally reactive material is higher. Sample 386-43-3, 135-138 cm, in particular, has an effective carbon content which is 50 per cent of its organic carbon value. Though the relationship between maceral composition and pyrolysis behavior is not precise, this comparison indicates that the amount of petroleum generated from a kerogen is affected by the kinds of organic matter of which it is made. 
J.W. KENDRICK, A. HOOD, J.R. CASTAÑO
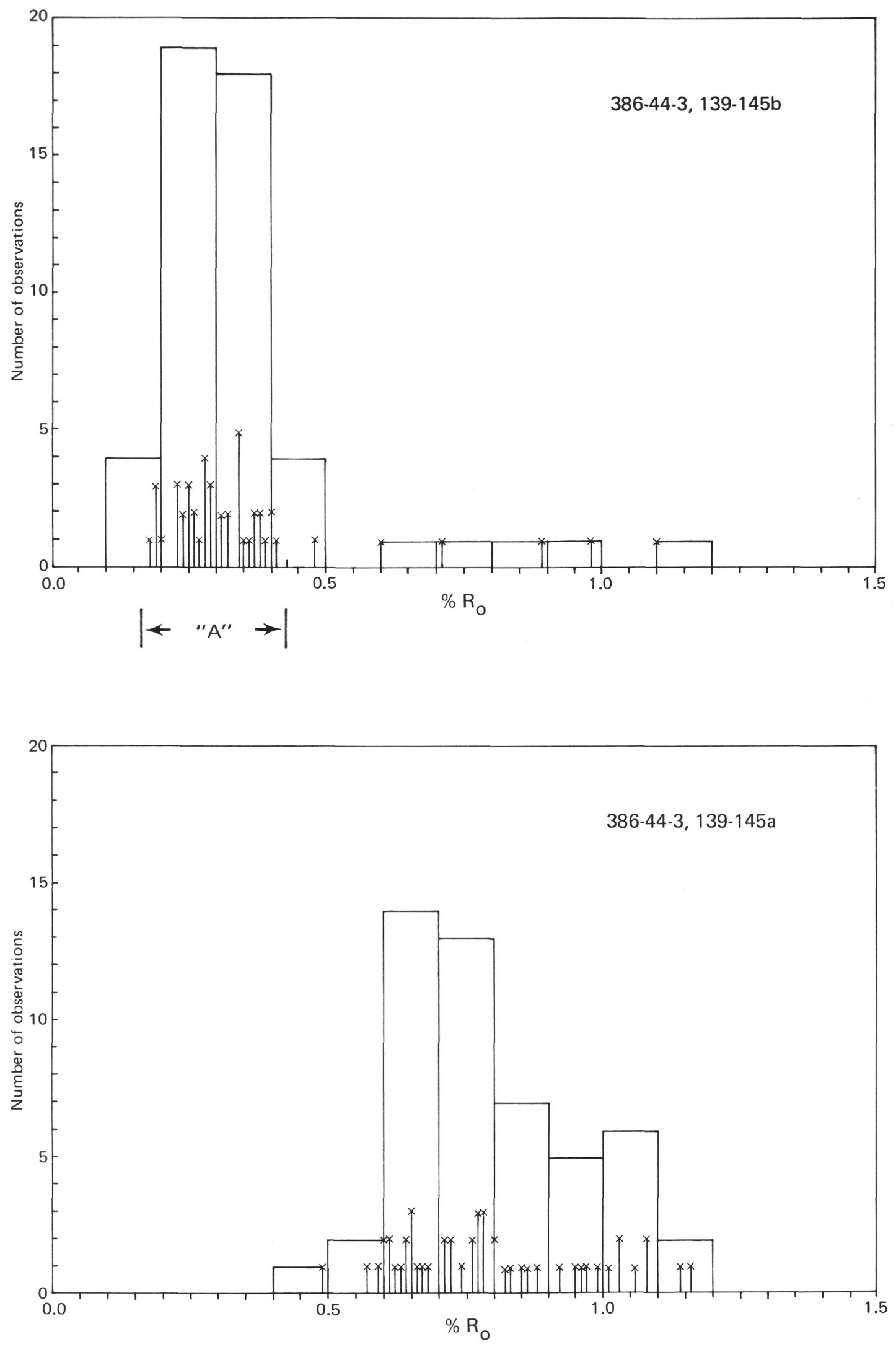

Figure 3. Histograms of vitrinite reflectance for samples containing (a) mainly primary vitrinite (386-44-3, 139-145b); (b) reworked vitrinite (386-44-3, 139-145a). A denotes the interpreted range of primary vitrinite values. 
PETROLEUM-GENERATING POTENTIAL OF CRETACEOUS SEDIMENTS
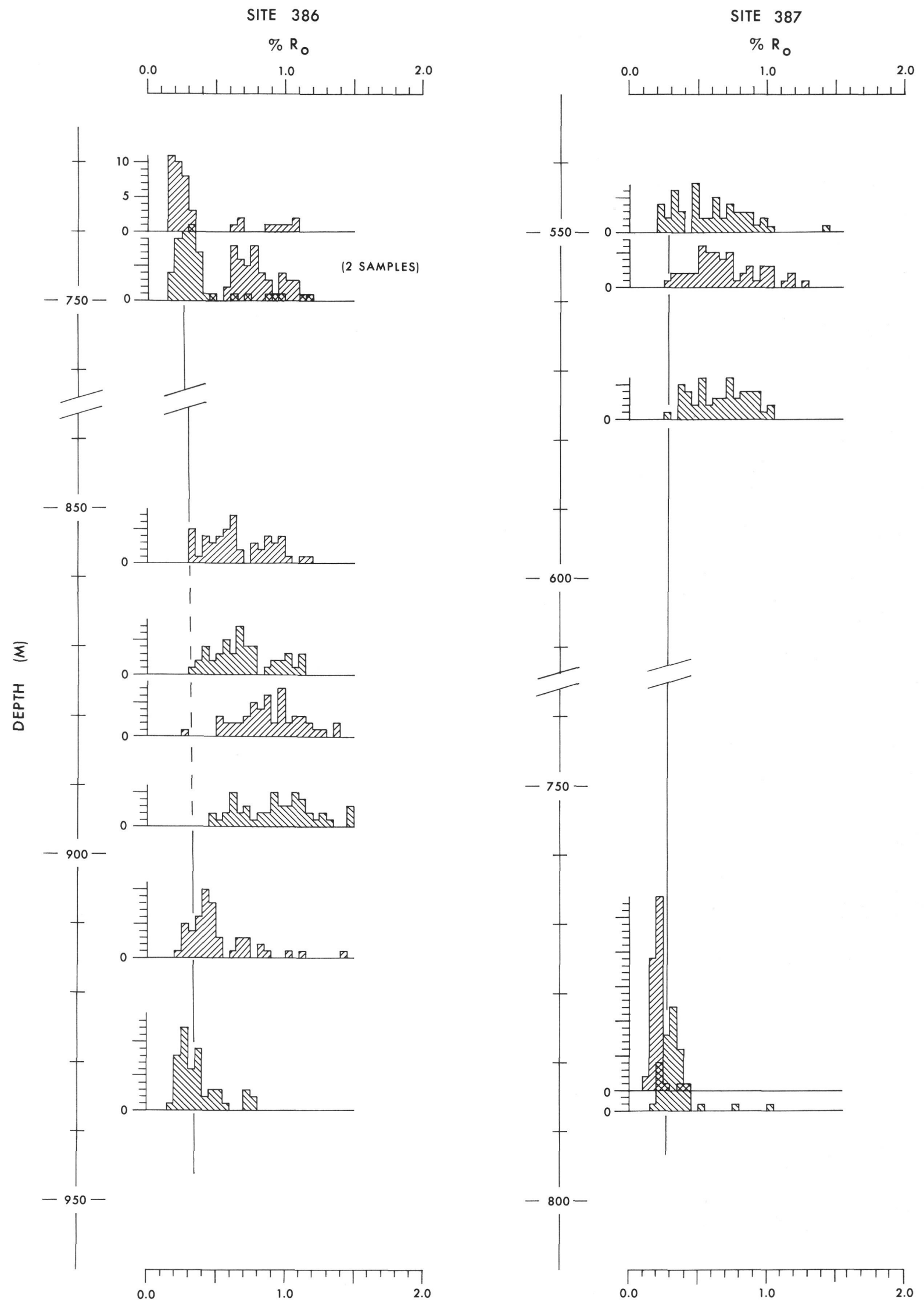

Figure 4. Histograms of vitrinite reflectance as a function of depth below sea floor at Sites 386 and 387. 
TABLE 2

Vitrinite Reflectance and Level of Organic Metamorphism

\begin{tabular}{|c|c|c|c|c|c|c|}
\hline \multirow[b]{2}{*}{$\begin{array}{c}\text { Sample } \\
\text { (Interval in } \mathrm{cm} \text { ) }\end{array}$} & \multirow[b]{2}{*}{$\begin{array}{c}\text { Depth } \\
\text { (m) }\end{array}$} & \multicolumn{4}{|c|}{ Vitrinite Reflectance (in Oil) } & \multirow[b]{2}{*}{ LOM $^{C}$} \\
\hline & & $\begin{array}{r}\text { No } \\
\text { Obser }\end{array}$ & $\begin{array}{l}\text { of } \\
\text { ations }\end{array}$ & Range of $\% \mathrm{R}_{\mathrm{o}}$ & Mean $\% \mathrm{R}_{\mathrm{o}}{ }^{\mathrm{b}}$ & \\
\hline \multicolumn{7}{|l|}{ Site 386} \\
\hline $43-3,135-138$ & 741 & $\begin{array}{l}\mathrm{A}^{(\mathrm{a})} \\
\mathrm{X}^{(\mathrm{a})}\end{array}$ & $\begin{array}{l}36 \\
46\end{array}$ & $\begin{array}{l}0.15-0.34 \\
0.15-1.69\end{array}$ & $\begin{array}{l}0.23 \pm 0.02 \\
0.39 \pm 0.10\end{array}$ & $\begin{array}{l}<7 \\
\text { n.d. }\end{array}$ \\
\hline $44-3,139-145 a$ & 750 & $\mathrm{X}$ & 50 & $0.49-1.16$ & $0.80 \pm 0.05$ & n.d. \\
\hline $44-3,139-145 b$ & 750 & $\begin{array}{l}\mathrm{A} \\
\mathrm{X}\end{array}$ & $\begin{array}{l}44 \\
50\end{array}$ & $\begin{array}{l}0.18-0.41 \\
0.18-1.10\end{array}$ & $\begin{array}{l}0.30 \pm 0.02 \\
0.36 \pm 0.06\end{array}$ & $\begin{array}{l}<7 \\
\text { n.d. }\end{array}$ \\
\hline $54-5,134-140$ & 858 & $\mathrm{X}$ & 50 & $0.30-1.17$ & $0.66 \pm 0.07$ & n.d. \\
\hline $\begin{array}{l}56-3,148-150 \\
57-3,137-142\end{array}$ & $\begin{array}{l}874 \\
883\end{array}$ & $\begin{array}{l}X \\
X\end{array}$ & $\begin{array}{l}50 \\
51\end{array}$ & $\begin{array}{l}0.33-1.14 \\
0.25-1.37\end{array}$ & $\begin{array}{l}0.70 \pm 0.07 \\
0.89 \pm 0.07\end{array}$ & $\begin{array}{l}\text { n.d. } \\
\text { n.d. }\end{array}$ \\
\hline $58-5,147-150$ & 896 & $\mathrm{X}$ & 50 & $0.45-1.63$ & $0.97 \pm 0.08$ & n.d. \\
\hline $605,138-141$ & 915 & A & 37 & $0.24-0.54$ & $0.40 \pm 0.03$ & $<7$ \\
\hline $63-1,137-142$ & 937 & $\begin{array}{l}\mathrm{X} \\
\mathrm{A} \\
\mathrm{Y}\end{array}$ & $\begin{array}{l}50 \\
43 \\
50\end{array}$ & $\begin{array}{l}0.24-1.43 \\
0.21-0.54\end{array}$ & $\begin{array}{l}0.51 \pm 0.07 \\
0.33 \pm 0.03\end{array}$ & $\begin{array}{l}\text { n.d. } \\
<7\end{array}$ \\
\hline & & $\mathrm{X}$ & 50 & $0.17-0.77$ & 0.31 & n.a. \\
\hline \multicolumn{7}{|l|}{ Site 387} \\
\hline $35-3,140-145$ & 550 & $\mathrm{X}$ & 51 & $0.23-1.44$ & $0.58 \pm 0.08$ & n.d. \\
\hline $36-2,140-145$ & 558 & $\mathrm{X}$ & 51 & $0.26-1.25$ & $0.70 \pm 0.07$ & n.d. \\
\hline $37-1,146-150$ & 576 & $\mathrm{X}$ & 50 & $0.25-1.04$ & $0.66 \pm 0.06$ & n.d. \\
\hline $49-2,143^{\mathrm{d}}$ & 784 & A & 51 & $0.13-0.35$ & $0.20 \pm 0.01$ & $<7$ \\
\hline & & $\mathrm{X}$ & 51 & $0.13-0.35$ & $0.20 \pm 0.01$ & $<7$ \\
\hline $49-4,4-8$ & 787 & A & 47 & $0.18-0.43$ & $0.31 \pm 0.02$ & $<7$ \\
\hline & & $\mathrm{X}$ & 50 & $0.18-1.01$ & $0.34 \pm 0.04$ & n.d. \\
\hline
\end{tabular}

(a) $\mathrm{X}$ represents the range of all vitrinite reflectance measurements; A represents the range of reflectance measurements interpreted to be primary vitrinite.

(b) $\% \mathrm{R}_{\mathrm{O}} \pm 95 \%$ confidence limit.

(c) All $R_{0}$ values less than $0.43 \%$ are assigned LOM $<7$ because of the difficulty of resolving the LOM $0-7$ range by means of vitrinite reflectance. $R_{0}$ values $\geqslant 0.43 \%$ are converted to LOM on the basis of Castano's $\mathrm{R}_{\mathrm{o}}$-LOM relationship (Hood and Castano, 1974). LOM's are given only for samples of primary vitrinite. n.d. = not determined.

(d) Sample 49-2, 143 represents a fragment of wood imbedded in limestone.

\section{ACKNOWLEDGMENT}

The authors wish to thank P. R. Mommessin for his review of this manuscript.

\section{REFERENCES}

Hayes, D. E., Pimm, A. C., et al., 1972. Initial Reports of the Deep Sea Drilling Project, v. 14: Washington (U.S. Government Printing Office).

Hollister, C. D., Ewing, J. I., et al., 1972. Initial Reports of the Deep Sea Drilling Project, v. 11: Washington. (U.S. Government Printing Office).

Hood, A. and Castaño, J. R., 1974. Organic metamorphism: Its relationship to petroleum generation and application to
TABLE 3

Relative Abundance of Types of Organic Matter by Visual Kerogen Analysis ${ }^{\text {a }}$

\begin{tabular}{lcccc}
\hline $\begin{array}{c}\text { Sample } \\
\text { (Interval in cm) }\end{array}$ & $\begin{array}{c}\text { Amorphous } \\
\text { Kerogen }\end{array}$ & Liptinite & Vitrinite & Inertinite \\
\hline Site 386 & & & & \\
$43-3,135-138$ & 6 & 1 & 5 & 2 \\
$44-3,139-145 \mathrm{a}$ & 1 & 1 & 7 & 1 \\
$44-3,139-145 \mathrm{~b}$ & 3 & 1 & 7 & 3 \\
$54-5,134-140$ & 1 & 1 & 7 & 3 \\
$56-3,148-150$ & 1 & 1 & 7 & 1 \\
$57-3.137-142$ & 1 & 1 & 7 & 2 \\
$58-5,147-150$ & 1 & 1 & 7 & 3 \\
$60-5,138-141$ & 1 & 1 & 7 & 3 \\
$63-1,137-142$ & 2 & & 7 & 4 \\
Site 387 & & 2 & & \\
$35-3,140-145$ & 2 & 2 & 6 & 5 \\
$36-2,140-145$ & 2 & 1 & 7 & 5 \\
$37-1,146-150$ & 1 & 2 & 7 & 1 \\
$49-2,143$ & 1 & 2 & 5 & 3 \\
$49-4,4-8$ & 6 & & & 4 \\
\hline
\end{tabular}

${ }^{a}$ Numerical abundance scale and percentages (by area): $1=0-1 \%$; $2=2-5 \% ; 3=6-10 \% ; 4=11-25 \% ; 5=26-50 \% ; 6=51-75 \% ; 7=76-$ $100 \%$.

studies of authigenic minerals: United Nations ESCAP, CCOP Tech. Bull., V. 8, p. 85-118.

Hood, A., Gutjahr, C. C. M., and Heacock, R. L., 1975. Organic metamorphism and the generation of petroleum, Am. Assoc. Petroc. Geol. Bull., V. 59, p. 986-996.

Hood, A., Castaño, J. R., and Kendrick, J. W., 1976. Petroleum-generating potential and thermal history of DSDP Leg 38 sediments, In Talwani, J., Udintsev, G., et al., Initial Reports of the Deep Sea Drilling Project, v. 38: Washington (U.S. Government Printing Office), p. 801-804.

Ronov, A. B., 1958. Organic carbon in sedimentary rocks (in relation to the presence of petroleum): Geochemistry, no. 5, p. $510-536$.

Schrayer, G. J. and Zarella, W. M., 1963. Organic geochemistry of Shales-I. Distribution of organic matter in siliceous Mowry Shale of Wyoming: Geochim. Cosmochim Acta, v. 27, p. 1033, 1046.

Vassoyevich, N. B., Korchagina, Yu. I., Lopatin, N. V., and Chernyshev, V. V., 1970. Principal phase of oil formation: Internat. Geol. Rev., v. 12, p. 1276-1296. 